\title{
Fetal birth weight, a challenge to the mother and simplest marker for fetal maturity: a study in new rural hospital setup
}

\author{
Rajashree Dattatreya Nagarashi, Lakshmi Swapna Durvasula*
} Department of Obstetrics and Gynecology, Gayatri Vidya Parishad Institute of Health Care and Medical Technologies,
Visakhapatnam, Andhra Pradesh, India

Received: 19 August 2019

Accepted: 30 September 2019

*Correspondence:

Dr. Lakshmi Swapna Durvasula,

E-mail: swapnam1131@gmail.com

Copyright: (c) the author(s), publisher and licensee Medip Academy. This is an open-access article distributed under the terms of the Creative Commons Attribution Non-Commercial License, which permits unrestricted non-commercial use, distribution, and reproduction in any medium, provided the original work is properly cited.

\section{ABSTRACT}

Background: The birth weight is an important factor which the obstetricians have to give due importance when contemplating elective induction of labor before 40 completed weeks. It is a single most important determinant for survival, growth and development of infant. It reflects the health status of the mother during adolescence and pregnancy and also the quality of antenatal care. It is well known that there is a co-relation between weight of the fetus and the length of the gestation and other various factors. This study looks into the various factors influencing the fetal birth weight and length of gestation and what is its relative importance to the viability of developmental chances of premature infants and also infants born at term. Objective was to study the effect of various maternal factors like maternal age, parity, maternal weight, gestational age on fetal birth weight.

Methods: 176 participants with term pregnancies were studied under three independent variables viz gestational age, maternal age and maternal weight that had effect on the fetal birth weight in two groups - primipara and multipara and reported by statistical analysis.

Results: The independent variables gestational age and maternal weight showed a statistically significant correlation $(\mathrm{p}<0.05)$ with fetal birth weight in both the groups. Whereas the variable maternal age didn't have any statistically significant effect $(\mathrm{p}>0.05)$ on the fetal birth weight in the study.

Conclusions: Primipara had more pronounced correlation with fetal birth weight than multipara in the variable gestational age. The maternal weight affected fetal birth weight equally in both the groups. And maternal age had no effect on fetal birth weight in either groups.

Keywords: Fetal birth weight, Gestational age, Maternal age, Maternal weight, Parity

\section{INTRODUCTION}

According to WHO "Healthy development of a child is of basic importance". And the concern for child health and survival is expressed at $34^{\text {th }}$ World Health Assembly where WHO adopted as a part of the global strategy for "Health for all by year 2020" the proportion of infants born with low birth weight (LBW) as one of the global indicators to monitor progress. ${ }^{1}$ The birth weight of an infant is the single most important determinant of survival, healthy growth and development. Many newborns die during their first year of life. ${ }^{2}$ Low birth weight, as one of the principal causes of infant mortality in India, needs to be addressed. Infant mortality rate (IMR) is universally regarded as, not only the most important indicator of the health status of a community but also the effectiveness of MCH services in particular. According to international agreement, low birth weight is defined as - birth weight $<2500 \mathrm{gms}$. It is one of the major challenges for $\mathrm{MCH}$ in developing countries. It has a number of public health consequences like mental retardation, high risk of perinatal and infant mortality as 
well as morbidity and very high cost of special care and intensive care unit (ICU). ${ }^{3}$

Fetal weight at birth is directly influenced by the mother who serves as a primary requisite for the birth of a healthy baby. Therefore, it is incumbent on her, to see that she accepts into her system the elements needed for a healthy pregnancy. It is well known that there is a relationship between the weight of the fetus and the length of gestation, but both these elements may be affected by a variety of factors, which are of importance to the viability and developmental potential of preterm infant and of those born at term.

In discussing the relation between the length of gestation and the birth weight, the fact must be borne in mind that both the elements of this relation are conditioned in many different ways and show a wide variability. Its value in routine clinical practice as a general guide to the degree of maturity of an infant, but other more precise measurement needs to be developed. The problem is a very old one.

\section{METHODS}

This is a retrospective study conducted in GVPIHC, New rural medical college, Visakhapatnam from July 17 to Sep'18. The study was conducted to evaluate the important variables in the mother that have an effect on the fetal birth weight. Various factors affecting fetal weight like maternal weight, maternal age, parity, gestational age are evaluated and a co-relation is established between the factors by applying statistical analysis coefficient of co-relation and P-value.

One hundred and seventy six participants with term pregnancies were included in the study. The inclusion criteria of the women consisted of maternal age between 18 - 35 years, gestational age between 36 - 41 weeks and maternal weight $45 \mathrm{~kg}$ in $1^{\text {st }}$ trimester of gestation to $100 \mathrm{~kg}$ with mean of $60 \mathrm{~kg}$ with singleton pregnancy. The exclusion criteria consisted of multiple gestation and obstetrical complications. The participants were divided into two groups: primipara and multipara and the effect of each variable on the birth weight in each group was studied and quantified. The no. of participants in primipara group were 82 with $\mathrm{n}=82$ and in multipara group were 94 with $n=94$. Signed informed consent was also obtained from all participants.

\section{Statistical analysis}

The sample size was determined to be 82 cases in case of primipara and 94 in case of multipara with a total of 176 participants. Some participants were not included in some variables due to non-availability of data. Data was analyzed and reported only for patients with complete information. Statistical analysis of data was performed using Microsoft excel data analytics pack software. Multiple $\mathrm{R}$ test and $\mathrm{P}$ value were used to determine the co-relation between the variables. The $\mathrm{p}$ values of less than 0.05 were considered significant.

\section{RESULTS}

Total of 176 participants were included in the study. The results included three variables gestational age, maternal age and maternal weight.

Table 1: Means of the variables studied in primipara and multipara group.

\begin{tabular}{|lll|}
\hline & $\begin{array}{l}\text { Primipara } \\
\text { group }\end{array}$ & $\begin{array}{l}\text { Multipara } \\
\text { group }\end{array}$ \\
\hline Mean gestational age & 39.025 & 38.275 \\
\hline Mean maternal age & 22.575 & 25.21739 \\
\hline Mean maternal weight & 63.981 & 63.19444 \\
\hline
\end{tabular}

Table 2: Regression analysis of gestational age on fetal birth weight in primipara patients.

\begin{tabular}{|c|c|c|c|c|c|c|c|c|}
\hline Multiple R & 0.482296 & & & & & & & \\
\hline R Square & 0.23261 & & & & & & & \\
\hline Adjusted R & 0.223017 & & & & & & & \\
\hline Standard E & 0.339015 & & & & & & & \\
\hline Observation & 82 & & & & & & & \\
\hline \multicolumn{9}{|l|}{ ANOVA } \\
\hline & Dff & SS & MS & $\mathbf{F}$ & Significance F & & & \\
\hline Regression & 1 & 2.787005 & 2.787005 & 24.2494 & $4.47 \mathrm{E}-06$ & & & \\
\hline Residual & 80 & 9.194469 & 0.114931 & & & & & \\
\hline \multirow[t]{2}{*}{ Total } & 81 & 11.98147 & & & & & & \\
\hline & Coefficient & $\begin{array}{l}\text { Standard } \\
\text { error }\end{array}$ & T stat & p-value & Lower $95 \%$ & $\begin{array}{l}\text { Upper } \\
95.0 \%\end{array}$ & $\begin{array}{l}\text { Lower } \\
95 \%\end{array}$ & $\begin{array}{l}\text { Upper } \\
95.0 \%\end{array}$ \\
\hline Intercept & -3.31873 & 1.268776 & -2.6157 & $1.06 \mathrm{E}-02$ & -5.84368 & -0.79379 & -5.84368 & -0.79379 \\
\hline Gest age & 0.159983 & 0.032488 & 4.924368 & $4.47 \mathrm{E}-06$ & 0.09533 & 0.224637 & 0.09533 & 0.224637 \\
\hline
\end{tabular}


Table 3: Regression analysis of gestational age on fetal birth weight in multipara patients.

\begin{tabular}{|c|c|c|c|c|c|c|c|c|}
\hline Multiple R & 0.287597 & & & & & & & \\
\hline R Square & 0.082712 & & & & & & & \\
\hline Adjusted R & 0.072741 & & & & & & & \\
\hline Standard E & 0.394464 & & & & & & & \\
\hline Observation & 94 & & & & & & & \\
\hline \multicolumn{9}{|l|}{ ANOVA } \\
\hline & Dff & SS & MS & $\mathbf{F}$ & Significan & & & \\
\hline Regression & 1 & 1.290819 & 1.29819 & 8.29565 & 0.004944 & & & \\
\hline Residual & 92 & 14.31538 & 0.155602 & & & & & \\
\hline \multirow[t]{2}{*}{ Total } & 93 & 15.6062 & & & & & & \\
\hline & Coefficient & $\begin{array}{l}\text { Standard } \\
\text { error }\end{array}$ & T stat & p-value & $\begin{array}{l}\text { Lower } \\
95 \%\end{array}$ & $\begin{array}{l}\text { Upper } \\
95.0 \%\end{array}$ & $\begin{array}{l}\text { Lower } \\
95 \%\end{array}$ & $\begin{array}{l}\text { Upper } \\
95.0 \%\end{array}$ \\
\hline Intercept & -1.52867 & 1.541554 & -0.99165 & $3.24 \mathrm{E}-01$ & -4.59033 & 1.532984 & -4.59033 & 1.532984 \\
\hline Gest Age & 0.115961 & 0.040261 & 2.880217 & 0.004944 & 0.035999 & 0.195923 & 0.035999 & 0.195923 \\
\hline
\end{tabular}

Table 4: Regression analysis of maternal age on fetal birth weight in primipara patients.

\begin{tabular}{|c|c|c|c|c|c|c|c|c|}
\hline Multiple R & 0.03321777 & & Adjusted R & \multicolumn{5}{|c|}{-0.11382787} \\
\hline R Square & 0.00110342 & & Standard E & \multicolumn{5}{|c|}{0.386785693} \\
\hline Observation & 82 & & & & & & & \\
\hline \multicolumn{9}{|l|}{ ANOVA } \\
\hline & Dff & SS & MS & $\mathbf{F}$ & \multicolumn{4}{|c|}{ Significance F } \\
\hline Regression & 1 & 0.013221 & 0.013221 & 0.088371 & \multicolumn{4}{|c|}{0.767029} \\
\hline Residual & 80 & 11.96825 & 0.149603 & & & & & \\
\hline \multirow[t]{2}{*}{ Total } & 81 & 11.98147 & & & & & & \\
\hline & Coefficient & $\begin{array}{l}\text { Standard } \\
\text { error }\end{array}$ & T stat & p-value & $\begin{array}{l}\text { Lower } \\
95 \%\end{array}$ & $\begin{array}{l}\text { Upper } \\
95.0 \%\end{array}$ & $\begin{array}{l}\text { Lower } \\
95 \%\end{array}$ & $\begin{array}{l}\text { Upper } \\
95.0 \%\end{array}$ \\
\hline Intercept & 3.009969072 & 0.284135 & 10.59346 & $6.82 \mathrm{E}-17$ & 2.444523 & 3.575415 & 2.444523 & 3.575415 \\
\hline$M$ age & -.003699332 & 0.012444 & -0.29727 & 0.767029 & -0.02846 & 0.021065 & -0.02846 & 0.021065 \\
\hline
\end{tabular}

Table 5: Regression analysis of maternal age on fetal birth weight in multipara patients.

\begin{tabular}{|c|c|c|c|c|c|c|c|c|}
\hline Multiple R & 0.201459 & & & & & & & \\
\hline R Square & 0.040586 & & & & & & & \\
\hline Adjusted R & 0.029926 & & & & & & & \\
\hline Standard E & 0.401225 & & & & & & & \\
\hline Observation & 92 & & & & & & & \\
\hline \multicolumn{9}{|l|}{ ANOVA } \\
\hline & Dff & SS & MS & $\mathbf{F}$ & Significance $\mathbf{F}$ & & & \\
\hline Regression & 1 & 0.612895 & 0.612895 & 3.807247 & 0.054141 & & & \\
\hline Residual & 90 & 14.48832 & 0.160981 & & & & & \\
\hline \multirow[t]{2}{*}{ Total } & 91 & 15.10121 & & & & & & \\
\hline & Coefficient & $\begin{array}{l}\text { Standard } \\
\text { error }\end{array}$ & T stat & p-value & Lower $95 \%$ & $\begin{array}{l}\text { Upper } \\
95.0 \%\end{array}$ & $\begin{array}{l}\text { Lower } \\
95 \%\end{array}$ & $\begin{array}{l}\text { Upper } \\
95.0 \%\end{array}$ \\
\hline Intercept & 2.360567 & 0.281645 & 8.38136 & $6.64 \mathrm{E}-13$ & 1.80103 & 2.920103 & 1.80103 & 2.920103 \\
\hline M age & 0.021551 & 0.011045 & 1.951217 & 0.054141 & -0.00392 & 0.043493 & -0.00039 & 0.043493 \\
\hline
\end{tabular}

Each of the variables in each group primipara and multipara were studied and their individual effect on birth weight was determined. Means of the variables studied in primipara and multipara groups are given in Table 1. The first variable compared the effect of gestational age on fetal birth weight. In case of primipara as indicated in Table 2, with $\mathrm{n}=82$, a significant correlation was established between gestational age and birth weight with $r(80)=0.48 ; p<0.05$ and in multipara as indicated in Table 3 a significant correlation was established when $n$ $=94$; with $\mathrm{r}(92)=0.28$ and $\mathrm{p}<0.05$, but the relation being more pronounced in case of primipara. The second variable compared the effect of maternal age on fetal birth weight. In case of primipara as indicated in Table 4, 
no significant co-relation was established where sample size $(\mathrm{n})=82$ with $\mathrm{r}(80)=0.33$ with $\mathrm{p}>0.05$ and in a multipara as indicated in Table 5 , also no significant corelation was established where sample size $(n)=94$ with $r$ $(92)=0.2014$ with $p>0.05$. Third variable studied was the effect of maternal weight on the birth weight. In
Primipara as indicated in Table 6 , with $\mathrm{n}-55$, there was a significant relation between the variables with $\mathrm{r}(53)=$ 0.33 and $\mathrm{p}<0.05$ and in case of multipara as indicated in Table 7, with $\mathrm{n}=72$, a significant relation was established between the variables with $\mathrm{r}(70)=0.328$ and $\mathrm{p}<0.05$.

Table 6: Regression analysis of maternal weight on fetal birth weight in primipara patients.

\begin{tabular}{|lllllllll|}
\hline Multiple R & 0.334622 & & & & & & \\
\hline R Square & 0.111972 & & & & & \\
\hline Adjusted R & 0.095217 & & & & & \\
\hline Standard E & 0.367239 & & & & & & \\
\hline Observation & 55 & & & & & & \\
\hline ANOVA & & & & & & & \\
\hline & Dff & SS & MS & F & Significance F & \\
\hline Regression & 1 & 0.901274 & 0.901274 & 6.682813 & 0.012522418 & & \\
\hline Residual & 53 & 7.147817 & 0.134864 & & & & & \\
\hline Total & 54 & 8.049091 & & & & Upper & Lower & Upper \\
\hline & Coefficient & $\begin{array}{l}\text { Standard } \\
\text { error }\end{array}$ & T stat & p-value & Lower 95\% & $\mathbf{9 5 . 0 \%}$ & $\mathbf{9 5 \%}$ & $\mathbf{9 5 . 0 \%}$ \\
\hline Intercept & 2.276296 & 0.254915 & 8.929632 & $3.78 \mathrm{E}-12$ & 1.76500172 & 2.787591 & 1.765002 & 2.787591 \\
\hline M wt & 0.010129 & 0.003918 & 2.585114 & 0.012522 & 0.002270139 & 0.017988 & 0.00227 & 0.017988 \\
\hline
\end{tabular}

Table 7: Regression analysis of maternal weight on fetal birth weight in multipara patients.

\begin{tabular}{|c|c|c|c|c|c|c|c|c|}
\hline Multiple R & 0.328161 & & & & & & & \\
\hline R Square & 0.107689 & & & & & & & \\
\hline Adjusted R & 0.094942 & & & & & & & \\
\hline Standard E & 0.36795 & & & & & & & \\
\hline Observation & 72 & & & & & & & \\
\hline \multicolumn{9}{|l|}{ ANOVA } \\
\hline & Dff & SS & MS & $\mathbf{F}$ & Significance $F$ & & & \\
\hline Regression & 1 & 1.143753 & 1.143753 & 8.448014 & 0.004890102 & & & \\
\hline Residual & 70 & 9.477108 & 0.135387 & & & & & \\
\hline \multirow[t]{2}{*}{ Total } & 71 & & & & & & & \\
\hline & Coefficient & $\begin{array}{l}\text { Standard } \\
\text { error }\end{array}$ & T stat & p-value & Lower $95 \%$ & $\begin{array}{l}\text { Upper } \\
95.0 \%\end{array}$ & $\begin{array}{l}\text { Lower } \\
95 \%\end{array}$ & $\begin{array}{l}\text { Upper } \\
95.0 \%\end{array}$ \\
\hline Intercept & 2.331118 & 0.204298 & 11.41039 & $1.25 \mathrm{E}-17$ & 1.923658952 & 2.738577 & 1.923659 & 2.738577 \\
\hline M wt & 0.009182 & 0.003159 & 2.906547 & 0.00489 & 0.002881519 & 0.015483 & 0.002882 & 0.015483 \\
\hline
\end{tabular}

\section{DISCUSSION}

In the hospital GVPIHCMT, Visakhapatnam, the study was conducted from July 18 to September 18. It included 176 participants and results were studied under three variables that had effect on the fetal birth weight.

A significant co-relation between the period of gestation and fetal birth weight was established with $\mathrm{p}<0.05$ as indicated in Figure 1 and 2. Similar results were obtained by Das et al a significant positive co relation between birth weight and gestational age. ${ }^{4}$ Also by K. Das, R. Ganguly, R. Sinha and B.W. Ghosh "Inter relationship of birth weight with certain biological and socio economic factors". 5
From the results, it was said that birth weight is an unstable element. It is different in different countries, in different areas within individual countries and shows wide variation.

And there are various factors that influence the above variables like length of gestation, maternal weight and their importance to the viability and developmental chances of premature and mature infants is extensively studied and still under research. Genetic factors are among the most important of those affecting the fetal weight studied by B. M. Hota. ${ }^{6}$ The sex of the fetus, as is widely known is strictly genetically determined. It is also generally known that the weight of the female infant is, 
on an average lower than its male counterpart. The secondary importance of father like, the father's genetic code influences the fetal weight is studied by UCL Institute of Child Health (ICH) - 2014. ${ }^{7}$ The race factor may also play some role in determining the birth weight is shown by NIH study - 2015, who observed that by 39 weeks, fetuses of white mothers were largest followed by Hispanics and in black are the smallest. ${ }^{8}$

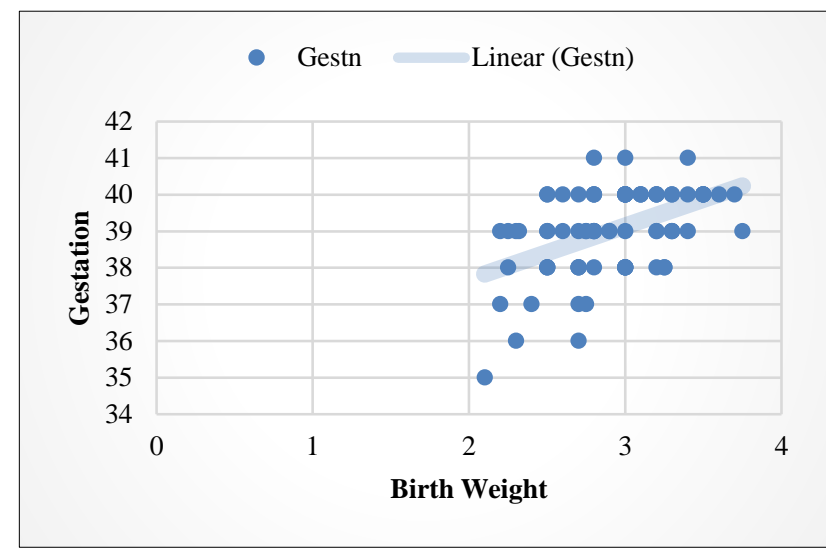

Figure 1: Graphical representation of regression analysis of Table 2 .

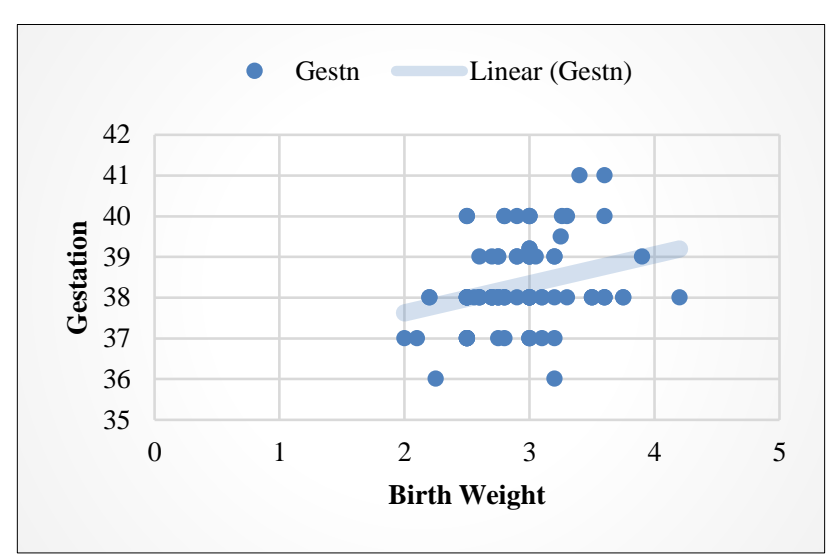

Figure 2: Graphical representation of regression analysis of Table 3 .

The reproductive conditions also may vary with age and parity of the women and similar factors influence the weight of the fetus. E Hurst assumes with some justification that the weight of the fetus is influenced to a greater extent by the environment the mother creates during its intrauterine development than by genetic characteristics of the fetus. ${ }^{9}$ Obviously, the closest environment of the developing fetus is its mother and her uterus and appendages - placenta and membranes etc. Their functional efficiency conditioned preconceptionally may play an important role in their later development and some definite characteristics weight of the fetus.

Size at birth is the strongest determinant of perinatal survival, it would appear that all fetal growth is subject to some degree of restraint by the maternal uterine environment reflecting the importance of the mother in restricting the nutritional demands of the fetus, if it would threaten her survival in times of poor nutrition studied by Moore V.M., Daries M.J. ${ }^{10,11}$ Although maternal undernutrition may or may not be less common determinant of birth weight in contemporary population, restraint is still evident in first pregnancies according to Mathew F, Yudkin P. ${ }^{12}$

Any nutritional factor in the maternal blood has to pass the placental membranes to reach the fetal blood. Placental weight is an independent determinant of fetal growth and birth weight and modifies the association between maternal metabolic factors and fetal growth. ${ }^{13}$

The next variable established a correlation between maternal weight and birth weight with $\mathrm{p}<0.05$ as indicated by Figure 3 and 4. Maternal weight showed a strong positive correlation with birth weight and showed statistical significance with $\mathrm{p}<0.05$ in studies by Mohanty et al. Maternal weight is the strongest determinant of fetal weight. ${ }^{14}$ Also similar results were obtained by R. Jananthan, D.G.N.G. Wijesinghe and T. Sivananthaweri. ${ }^{15}$

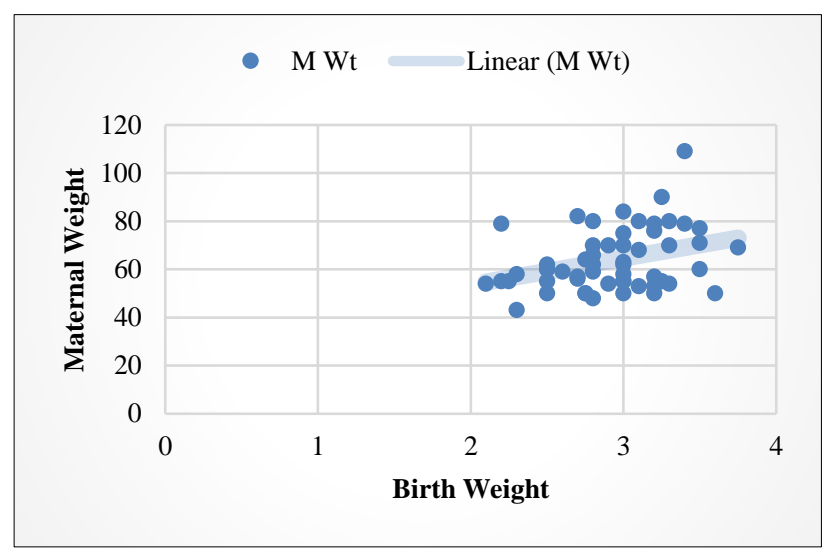

Figure 3: Graphical representation of regression analysis of Table 6 .

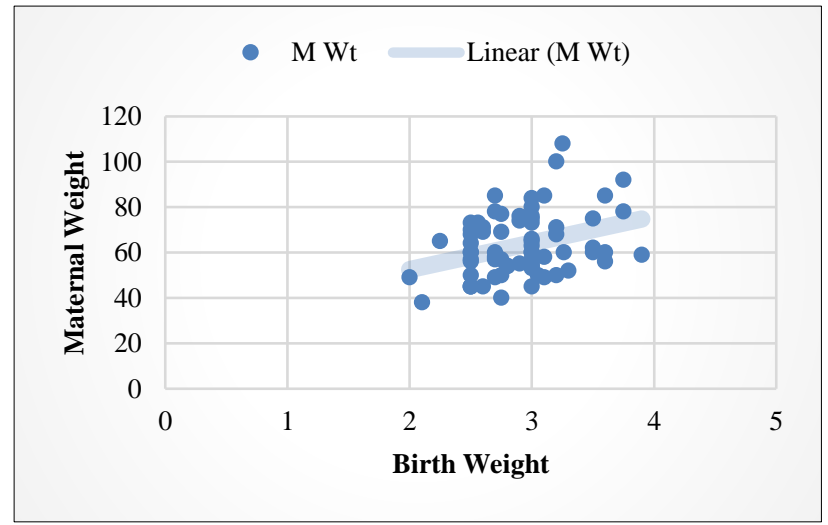

Figure 4: Graphical representation of regression analysis of Table 7. 
The other variable studied was maternal age and its influence on birth weight. Since the population was mainly rural and even the controls were of lesser age group and because of lesser age group even in multiparas, we couldn't establish a significant correlation between these variables with $\mathrm{p}>0.05$ as indicated by Figure 5 and 6. Some studies with similar result were done. ${ }^{16,17}$

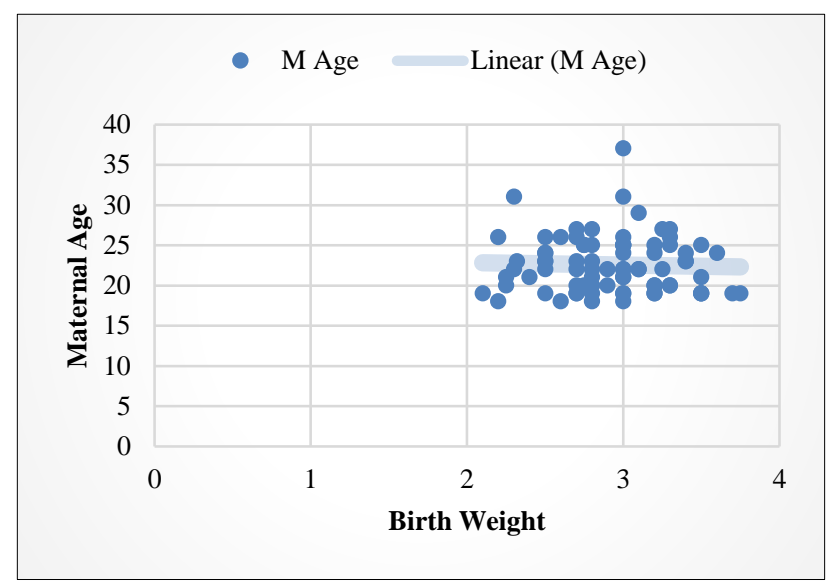

Figure 5: Graphical representation of regression analysis of Table 4.

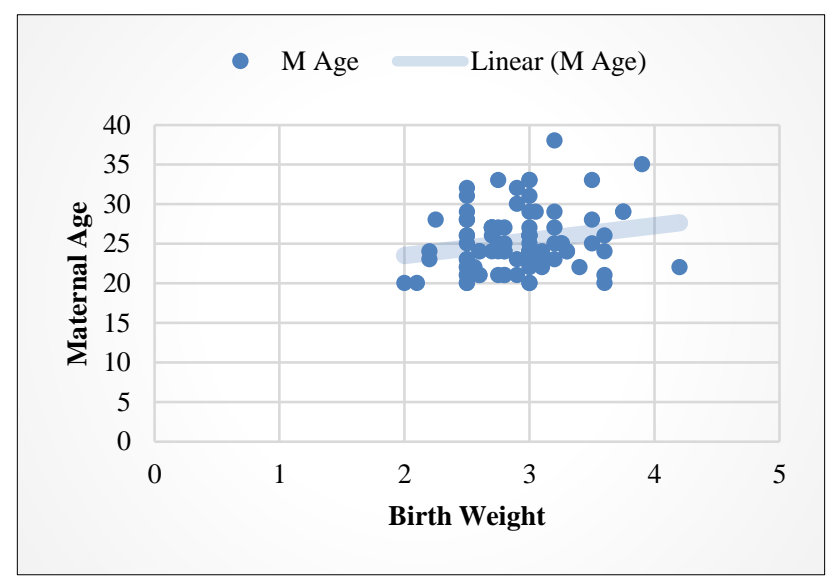

Figure 6: Graphical representation of regression analysis of Table 5.

But other studies, that studied the population group in sub urban communities like Neeraj Agarwal, V. P. Reddaiah, had established a significant correlation between maternal age and fetal birth weight and stressed on the importance of avoiding teenage pregnancies and adopting various family planning norms provided by the Govt. of India.

Very young mothers tend to be poor and less educated. Illiteracy is a greater barrier to any improvement in the health conditions. Education of females as a driving force for better health has been extensively studied. Women with schooling tend to marry later, delay child bearing and adopt family planning norms with wider spacing between births. They make better use of health care facilities and have better access to information related to personal hygiene and care of their children.

\section{CONCLUSION}

From observations, following conclusions may be drawn:

- There is a considerable relationship between the weight of the fetus and the length of gestation more in primipara than multipara.

- There is only a slight correlation between the age of the mother and the weight of the fetus. Good correlation between maternal weight and birth weight irrespective of parity. In clinical routine, the weight in its relation to the length of gestation is important mainly for general estimation of maturity and of degrees of underweight of the fetus, because it is easily measured. So, it is a measure to postpone elective inductions till 39 weeks of gestation. Other more precise methods of determination of the maturity and biological viability of the fetus have yet to be developed.

The intrinsic environment in which the fetus develops during gestation the physiology of reproduction in its widest sense and especially the physiology of the fetus itself as well as of the uterine mucosa decidua, its relationship to the placenta must be considered as a field for further scientific research.

There are certain other possibilities also for further investigations among which should be most seriously considered. Research on the pre and post conceptional conditions of fetal development was done and on the genetic factors determining that development was studied. Such investigations might make a very practical contribution for facilitating estimation of the degree of maturity and of the biological qualities of the fetus.

\section{ACKNOWLEDGMENTS}

Authors would like to thank Dr. Subba Rao, Dr. Somaraju, Dr. D.V.S.S. Rama Murthy, Dr. T. S. Prasad, Dr. Vijaya Kumar, Mrs. Asha, Mrs. Latha, Miss. Revathi and sister Ganga Devi for their support during study.

\section{Funding: No funding sources}

Conflict of interest: None declared

Ethical approval: The study was approved by the Institutional Ethics Committee

\section{REFERENCES}

1. K Park. Preventive medicine in obstetrics, paediatrics and geriatrics, textbook of social and preventive medicine. $18^{\text {th }}$ Edition, Banarsi Das Bhanot, India. 2005:383-420.

2. Njokanma OTF, Goswami K. The effect of sex, parity and maternal age on birth weight in a specialist hospital setting in Nigeria. J Obstet Gynaecol. 2004;24(6):657-61.

3. Agarwal N, Reddaiah VP. Factors affecting birth weight in a sub urban community a study in 
secondary level hospital in Delhi, Health and Population. Perspectives Issues. 2005;28(4):189-96.

4. Salas A, Carlo WA, Ambavalanan N, Nolen TL, Stoll BJ, Das A. Gestational age and birth weight for risk assessment of neurodevelopmental impairment or death in extremely preterm infants. Arch Dis Child Fetal Neonatal Ed. 2016;101(6):494-501.

5. Das K, Ganguly SS, Saha R, Ghosh BN. Inter relationship of birth weight with certain biological and socio economic factors. Indian J Public Health. 1981;2:11-9.

6. Hota BM, Mova N. New born birth weight in normal pregnancy in rural Telangana. Journal NTR Uni Health Sci. 2017;6(4):232-5.

7. Moore G. Father's genetic code influences weight of baby: New study by UCL Institute of child health. PLOS One, 2014.

8. Catov JM, Lee M, Roberts JM, Xu J, Narsimhan H. Race disparities and decreasing birth weight: are all babies getting smaller? Am J Epidemiol. 2016;183(1):15-23.

9. Voo E, Hurst FJ. Maternal characteristics and expected birth weight. Eur J Obstet Gynecol Reprod Biol. 1993;50(2):115-22.

10. Ounsted M, Scorp A, Mour V.A. Constrained and unconstrained fetal growth association with some biological and pathological factors. Am Bum Biol. 1988;15:33-7.

11. Moore VM, Daries MJ. Dietary composition of pregnant women in relation to the size of the baby at birth. J Nutr. 2004;134:13-6.
12. Mathews F, Yudkin P, Neil A. Influence of maternal nutrition on outcome of pregnancy. Prospective Cohort study. 1999;319(7206):339-43.

13. Roland MC. Fetal growth versus birth weight: the role of placenta versus other determinants. PLoS One. 2012;7(6):39324.

14. Mohanty C, Prasad R, Reddy SA, Ghosh JK, Singh TB, Das BK. Maternal anthropometry as predictors of low birth weight. J Trop Pediatr. 2006;52(1):24-9.

15. Jananthan R, Wijesinghe DGNG, Sivananthawerl T. Maternal anthropometry as a predictor of birth weight. Tropical Agricul Res. 2009;21(1):89-98.

16. Macleod S, Kiely JL. The effects of maternal age and parity on birth weight a population based study in New York City. Int J Gynaecol Obstet. 1988;26(1):11-9.

17. Sen J, Mondal N. Association of maternal nutrition status, body composition and socio-economic variables with low birth weight in India. J Trop Pediatr. 2010;56(4):254-9.

Cite this article as: Nagarashi RD, Durvasula LS. Fetal birth weight, a challenge to the mother and simplest marker for fetal maturity: a study in new rural hospital setup. Int J Reprod Contracept Obstet Gynecol 2019;8:4291-7. 